\title{
Efektivitas Biolarvasida Ekstrak Daun Sirsak dan Serai Wangi terhadap Larva Nyamuk Aedes aegypti
}

\author{
Sefrinus M.D Kolo ${ }^{\mathrm{a}}$ Gergonius Fallo ${ }^{\mathrm{b}}$ Silvana Dewi Ratna Neno ${ }^{\mathrm{c}}$ \\ ${ }^{a}$ Program Studi Kimia, Universitas Timor, Kefamenanu, TTU-NTT, 85613, Indonesia, , email: sefriunimor@gmail.com \\ ${ }^{b}$ Program Studi Biologi, Universitas Timor, Kefamenanu, TTU-NTT, 85613, Indonesia \\ ${ }^{c}$ Program Studi Pendidikan Biologi, Universitas Timor, Kefamenanu, TTU - NTT, 85613, Indonesia
}

\section{Article Info}

Article history:

Received 8 Mei 2018

Received in revised form 19 Juni 2018

Accepted 5 Juli 2018

\section{DOI:}

https://doi.org/10.32938/slk.v1i1.441

Keywords:

Ekstrak

Daun Sirsak

Serai Wangi

Larva Aedes aegypt

$\mathrm{LC}_{5}$

\section{Pendahuluan}

Demam Berdarah Dengue (DBD) adalah penyakit yang disebabkan oleh infeksi virus yang secara endemis berada di Indonesia dan telah menimbulkan persoalan kesehatan masyarakat. Infeksi virus DBD terjadi melalui gigitan nyamuk Aedes aegypti dan Aedes albopictus, yang ditandai dengan demam mendadak 2 sampai 7 hari tanpa penyebab yang jelas, lemah atau lesu, gelisah, nyeri ulu hati, disertai tanda perdarahan di kulit berupa bintik perdarahan (petechie), lebam (echymosis), atau ruam (purpura), kadang-kadang mimisan, berak darah, muntah darah, kesadaran menurun atau renjatan (shock). Penyakit ini banyak menimbulkan masalah khususnya di daerah perkotaan (Sitio, 2008). Berdasarkan data dari profil kesehatan Provinsi Nusa Tenggara Timur (NTT) Tahun 2012, DBD adalah penyakit berpotensi kejadian luar biasa (KLB)/wabah Penyakit ini menyerang sebagian besar anak usia $<15$ tahun, namun dapat juga menyerang orang dewasa. Di NTT pada tahun 2012 ditemukan sebanyak 1.542 kasus, dengan kasus tertinggi bahkan dinyatakan KLB oleh Pemkot yakni Kota Kupang (890 kasus). Angka kematian sebanyak 13 orang dengan Case Fatality Rate (CFR) sebesar $0,8 \%$, dan angka kematian tertinggi di Kota Kupang yaitu sebanyak 8 orang (CFR 0,9\%), menyusul Kabupaten Belu 3 orang meninggal, Kabupaten Ngada dan Sumba Timur masing-masing 1 orang meninggal. Pada tahun 2013 ditemukan kasus DBD sebanyak 2.986 kasus, dengan angka kematian sebanyak 8 orang di Kota Kupang dan Saburaijua sebanyak 7 orang. Pada tahun 2014 jumlah penderita DBD sebesar 487 kasus. Kasus tertinggi terjadi di Kabupaten Manggarai Barat, Kabupaten Sikka, Kota Kupang dan termasuk Kabupaten Timor Tengah Utara (TTU).

Pada saat ini pemberantasan Aedes aegypti merupakan cara utama yang dilakukan untuk memberantas DBD, karena vaksin untuk mencegah dan obat untuk membasmi virusnya belum tersedia. Pemberantasan Aedes aegypti dapat dilakukan terhadap nyamuk dewasa atau jentiknya. Pemberantasan terhadap jentik dapat dilakukan dengan cara kimia, biologi, dan fisik (Rosdiani, 2015).

Upaya pemberantasan DBD dititikberatkan pada penggerakan potensi masyarakat untuk dapat berperan serta dalam Pemberantasan Sarang Nyamuk (PSN) melalui gerakan 3M plus (Menguras, Menutup, Mengubur dan Menabur larvasida), penyebaran ikan pada tempat penampungan air serta kegiatankegiatan lainnya yang dapat mencegah/memberantas nyamuk Aedes aegypti berkembang biak (Harfriani, 2012).

Pemberantasan dengan cara kimia saat ini dapat dilakukan dengan larvasida yang dikenal dengan istilah abatisasi. Larvasida yang biasa digunakan adalah temefos. Temefos merupakan jenis insektisida yang tergolong ke dalam organofosfat, namun penggunaan insektisida dari bahan kimia ternyata menimbulkan banyak masalah baru diantaranya adalah pencemaran lingkungan seperti pencemaran air dan resistensi serangga terhadap insektisida sehingga dampak negatif dari penggunaan insektisida kimia maka perlu dicari alternatif lain yang lebih aman. Salah satunya adalah dengan menggunakan insektisida alami

Beberapa keanekaragaman tumbuhan yang dapat membunuh larva nyamuk, aman terhadap manusia, dan mudah didapatkan serta membawa dampak positif pada kesehatan manusia yaitu memanfaatkan tumbuhan sirsak dan serai wangi. Sirsak (Annona muricata L) memiliki bahan aktif yang terkandung dalam tumbuhan ini terdapat pada buah yang mentah, biji, akar, dan daunnya mengandung bahan aktif annonain, saponin, flavonoid, dan tanin. Selain itu, bijinya mengandung minyak antara $42-45 \%$. Daun dan bijinya dapat berperan sebagai insektisida dan larvasida repellent (penolak serangga) (Harfriani, 2012).

Serai wangi (Cymbopogon nardus L) merupakan tanaman dengan habitus terna perenial, serai wangi merupakan tanaman dari suku Poaceae yang sering disebut dengan suku rumput-rumputan (Wardani, 2009). Tanaman ini batang dan daunnya mengandung zat-zat seperti geraniol, metil heptenon, terpen-terpen, terpen-alkohol, asam-asam organik dan terutama sitronelal yang bisa dimanfaatkan sebagai penghalau nyamuk (Sumi Arcani dkk., 2017).

\section{Metode}

\subsection{Teknik pengambilan sampel}

Pengambilan sampel tanaman sirsak, dilokasi perkebunan masyarakat di Kelurahan Kefa Selatan, Maslete Kota Kefamenanu, Kabupaten Timor Tengah Utara (TTU). Sedangkan tanaman serai wangi diambil di Desa Oenenu, Kecamatan Bikomi Tengah, Kabupaten TTU. Tanaman yang diambil sebagai sampel yaitu daun. Daun diambil secukupnya dan dimasukan kedalam kantong plastik untuk selanjutnya dibawa ke laboratorium untuk diekstrak. Untuk pengambilan larva nyamuk Aedes aegypti, pengambilannya dilakukan ditempat penampungan air di BTN, desa Naiola, kecamatan Bikomi Selatan, kabupaten TTU. Larva yang dimasukan kedalam toples, setelah itu akan dibiarkan untuk nanti diambil dengan menggunakan spatula. Larva akan dipindahkan kedalam gelas beaker dengan menggunakan spatula, untuk ditetesi ekstrak dari daun sirsak dan serai wangi.

\subsection{Preparasi sampel}

Daun sirsak dan daun serai wangi $\pm 1 \mathrm{~kg}$, dicuci, lalu dikeringkan dan ditimbang masing-masing sebanyak 200 gr. Daun kemudian dicuci dan daun yang sudah kering diblender untuk mendapatkan serbuk daun ekstrak. Serbuk daun ekstrak diaduk dengan alkohol $70 \%$ secukupnya kurang lebih $600 \mathrm{ml}$ selama kurang lebih 2 jam agar seluruh serbuk daun sirsak dan serai wangi terendam secara merata. Setelah diaduk, sampel direndam atau didiamkan selama 24 jam.

2.3. Uji aktifitas ekstrak daun sirsak dan serai wangi sebagai larvasida terhadap nyamuk

Uji aktivitas ekstrak daun sirsak sebagai larvasida terhadap nyamuk dilakukan berdasarkan metode yang dikembangkan oleh WHO (1990). Disiapkan 6 buah gelas beaker masing-masing diberi label A,B,C,D,E dan F. Ke dalam 5 gelas beaker (A-E) ditambahkan masing-masing $50 \mathrm{ml}$ air dari perkembangbiakan larva kemudian ditambahkan ekstraksi daun sirsak dan serai wangi yang telah dicampur dengan alkohol $70 \%$, sehingga konsentrasi menjadi $0,75 \mathrm{ml}, 1 \mathrm{ml}, 1,5 \mathrm{ml}, 2 \mathrm{ml}$, dan $5 \mathrm{ml}$. Beaker ke- 6 dijadikan kontrol diisi dengan alkohol. Ke dalam setiap beaker dimasukan 10 ekor larva nyamuk Aedes aegypti, kemudian dilakukan pengamatan pada 20,45,65 dan 90 menit. Setiap waktu pengamatan, dihitung jumlah larva yang mati dari masing-masing beaker tersebut. Percobaan dilakukan sebanyak 3 kali.

Persen kematian larva dihitung dengan rumus (Kolo \& Oetpah, 2017):

$$
\mathrm{M}=\frac{\mathrm{Lp}-\mathrm{Lk}}{\mathrm{JL}} \times 100 \%
$$

Keterangan:

M: Persen mortalitas (kematian larva)

Lp: Jumlah larva yang mati pada kelompok perlakuan

Lk: Jumlah larva yang mati pada kelompok control

JL: Jumlah larva dalam masing-masing beaker

2.4. Teknik Analisa Data

Rancangan penelitian yang digunakan adalah Rancangan Acak Kelompok (RAK), dengan perlakuan konsentrasi ekstrak daun sirsak dan serai wangi yaitu $750 \mathrm{ppm}, 1000 \mathrm{ppm}, 1500 \mathrm{ppm}, 2000 \mathrm{ppm}$, dan 5000ppm dan jumlah ulangan sebanyak 3 kali dengan 15 kali percobaan. Untuk mengetahui beda nyata taraf perlakuan digunakan Uji Beda Nyata Jujur (BNJ), sedangkan untuk mengetahui konsentrasi efektif $\left(\mathrm{LC}_{50}\right)$ yang membunuh larva nyamuk menggunakan program Minitab 16 (Kolo \& Oetpah, 2017).

\section{Hasil dan Pembahasan \\ 3.1 Hasil}

3.1.1. Uji aktifitas ekstrak daun sirsak

Dari penelitian yang telah dilakukan untuk mengetahui efektivitas ekstrak daun sirsak (Annona muricata L) terhadap kematian larva nyamuk Aedes aegyti, 
diperoleh hasil berupa persentase jumlah larva yang mati, dapat dilihat pada Tabel 1.

Tabel 1. Persentase Kematian Larva Aedes aegypti dari Ekstrak Daun Sirsak

\begin{tabular}{llllll}
\multicolumn{7}{c}{ MORTALITAS $(\%)$} \\
\hline $\begin{array}{l}\text { Waktu/ } \\
\text { konsentrasi }\end{array}$ & $\begin{array}{l}\mathbf{7 5 0} \\
\text { ppm }\end{array}$ & $\begin{array}{l}\mathbf{1 0 0 0} \\
\text { ppm }\end{array}$ & $\begin{array}{l}\mathbf{1 5 0 0} \\
\mathbf{p p m}\end{array}$ & $\begin{array}{l}\mathbf{2 0 0 0} \\
\mathbf{p p m}\end{array}$ & $\begin{array}{l}\mathbf{5 0 0 0} \\
\mathbf{p p m}\end{array}$ \\
\hline 20 menit & 0 & 6.66 & 13.33 & 36.66 & 96.66 \\
\hline 45 menit & 26.66 & 43.33 & 46.66 & 56.66 & 100 \\
\hline 65 menit & 56.66 & 63.33 & 70 & 76.66 & 100 \\
\hline 90 menit & 66.66 & 66.66 & 86.66 & 96.66 & 100 \\
\hline
\end{tabular}

Pada Tabel 1 diatas, menunjukan bahwa persentase mortalitas (kematian larva) dari perlakuan konsentrasi ekstrak daun sirsak pada waktu yakni 20 menit, 45 menit, 65 menit dan 90 menit, diketahui bahwa kematian larva tertinggi terdapat pada konsentrasi 5000ppm pada waktu 90 menit dengan persentase (100\%). Sedangkan kematian larva terendah terjadi pada konsentrasi 750ppm pada waktu 20 menit dengan persentase (0\%). Hasil di atas menunjukan bahwa jumlah kematian larva meningkat seiring dengan peningkatan konsentrasi ekstrak daun sirsak dari konsentrasi terendah yaitu $750 \mathrm{ppm}$ hingga konsentrasi tertinggi yaitu 5000ppm.

\subsubsection{Uji aktifitas estrak daun serai wangi}

Penelitian yang telah dilakukan untuk mengetahui efektivitas ekstrak daun serai wangi (Cymbopogon nardus L) terhadap kematian larva nyamuk Aedes aegyti, diperoleh hasil berupa persentase jumlah larva yang mati, dapat dilihat pada Tabel 2.

Tabel 2. Persentase Kematian Larva Aedes aegypti dari Ekstrak Serai Wangi

\begin{tabular}{llllll}
\hline \multicolumn{7}{c}{ MORTALITAS (\%) } \\
\hline $\begin{array}{l}\text { Waktu/ } \\
\text { konsentrasi }\end{array}$ & $\begin{array}{l}\mathbf{7 5 0} \\
\mathbf{p p m}\end{array}$ & $\begin{array}{l}\mathbf{1 0 0 0} \\
\mathbf{p p m}\end{array}$ & $\begin{array}{c}\mathbf{1 5 0 0} \\
\mathbf{p p m}\end{array}$ & $\begin{array}{c}\mathbf{2 0 0 0} \\
\mathbf{p p m}\end{array}$ & $\begin{array}{c}\mathbf{5 0 0 0} \\
\mathbf{p p m}\end{array}$ \\
\hline 20 menit & 0 & 10 & 13,33 & 36,66 & 96,66 \\
\hline $\mathbf{4 5}$ menit & 26,66 & 36,66 & 43,33 & 46,66 & 100 \\
\hline 65 menit & 46,66 & 53,33 & 63,33 & 76,66 & 100 \\
\hline 90 menit & 60 & 73,33 & 83,33 & 96,66 & 100 \\
\hline
\end{tabular}

Pada Tabel 2 diatas, menunjukan bahwa persentase mortalitas (kematian larva) dari perlakuan konsentrasi ekstrak daun serai wangi pada waktu 20 menit, 45 menit, 65 menit dan 90 menit, diketahui bahwa kematian larva tertinggi terdapat pada konsentrasi 5000ppm pada waktu 90 menit dengan persentase $(100 \%)$. Sedangkan kematian larva terendah terjadi pada konsentrasi $750 \mathrm{ppm}$ pada waktu 20 menit dengan persentase $(0 \%)$. Hasil di atas menunjukan bahwa jumlah kematian larva meningkat seiring dengan peningkatan konsentrasi ekstrak daun serai wangi dari konsentrasi terendah yaitu 750ppm hingga konsentrai tertinggi yaitu 5000ppm.

\subsubsection{Perbandingan ekstrak daun sirsak dan serai wangi terhadap}

kematian larva nyamuk Aedes Aegypt

Perbandingan kematian larva nyamuk Aedes aegypti berdasarkan persentase kematian dilihat dari tabel $\mathbf{1}$ dan tabel 2, dapat diketahui bahwa dengan menggunakan ekstrak daun sirsak pada konsentrasi 1500ppm jumlah larva yang mati sebanyak $86,66 \%$ di menit ke 90 . Sedangkan saat menggunakan ekstrak daun serai wangi pada konsentrasi $1500 \mathrm{ppm}$ jumlah larva yang mati sebanyak 83,33\% di menit ke 90. Oleh karena itu, maka konsentrasi 1500ppm di menit ke 90 dari ekstrak daun sirsak lebih efektif mematikan larva dibandingkan ekstrak daun serai wangi.

3.1.4. Analisis data efektivitas larvasida ekstrak daun sirsak dan serai wangi

Hasil pendugaan nilai toksisitas ekstrak sirsak dan serai wangi yang efektif terhadap larva nyamuk Aedes aegypti ditentukan berdasarkan nilai Lethal Concentration $\left(\mathrm{LC}_{50}\right)$. Lethal Consentration $50\left(\mathrm{LC}_{50}\right)$ adalah suatu besaran yang diturunkan secara statistik, guna menyatakan dosis atau konsentrasi tunggal sesuatu senyawa yang diperkirakan dapat mematikan atau menimbulkan efek toksik yang berarti pada $50 \%$ hewan coba setelah perlakuan. $\mathrm{LC}_{50}$ merupakan tolak ukur kuantitatif yang sering digunakan untuk menyatakan kisaran dosis letal (Jenova, 2009).

Tabel 3. Tingkat toksisitas yang dinyatakan dalam $\mathrm{LC}_{50}$

\begin{tabular}{lll}
\hline No & Kelas & LC $_{\mathbf{5 0}}(\mathbf{m g} / \mathbf{K g B B})$ \\
\hline 1 & Luar biasa toksik & $<1$ \\
\hline 2 & Sangat toksik & $1-50$ \\
\hline 3 & Cukup toksik & $51-500$ \\
\hline 4 & Sedikit toksik & $501-5000$ \\
\hline 5 & Praktis tidak toksik & $5.000-15.000$ \\
\hline 6 & Kurang berbahaya & $>15.000$ \\
\hline
\end{tabular}

Tabel 3 di atas menunjukan bahwa semakin kecil nilai $\mathrm{LC}_{50}$, maka semakin tinggi toksisitas suatu senyawa dan sebaliknya, semakin besar nilai $\mathrm{LC}_{50}$, semakin rendah toksisitasnya (Jenova, 2009).
Tabel 4. Nilai LC $_{50}$ Ekstrak Daun Sirsak terhadap Larva Aedes aegypti

\begin{tabular}{ll}
\hline Lama kontak (menit) & LC $_{\mathbf{5 0}}(\mathbf{m g} / \mathbf{K g B B})$ \\
\hline 20 menit & 2768 \\
\hline 45 menit & 1528 \\
\hline 65 menit & 744 \\
\hline 90 menit & 214 \\
\hline
\end{tabular}

Tabel 5. Nilai $\mathrm{LC}_{50}$ Ekstrak Serai Wangi terhadap Larva Aedes aegypti

\begin{tabular}{ll}
\hline Lama kontak (menit) & $\mathbf{L C}_{\mathbf{5 0}}(\mathbf{m g} / \mathbf{K g B B})$ \\
\hline 20 menit & 2722 \\
\hline 45 menit & 1696 \\
\hline 65 menit & 971 \\
\hline 90 menit & 248 \\
\hline
\end{tabular}

Dari Tabel 4 dan Tabel 5 di atas menunjukkan bahwa semakin tinggi konsentrasi ekstrak daun sirsak dan serai wangi, semakin lama waktu kontak, maka aktivitas larvasida ekstrak daun sirsak dan serai wangi semakin tinggi. Hal ini disebabkan karena waktu kontak antara larva nyamuk dengan ekstrak daun sirsak dan serai wangi yang bersifat racun semakin lama.

Hasil analisis probit nilai $\mathrm{LC}_{50}$ terhadap konsentrasi daun sirsak dan serai wangi terlihat dalam Tabel 4 dan Tabel 5 dengan waktu kontak 20 menit, 45 menit, 65 menit dan 90 menit. Hasil transformasi analisis Minitab 16 dari ekstrak daun sirsak dan serai wangi terhadap konsentrasi didapatkan konsentrasi yang efektif untuk membunuh larva nyamuk terjdi pada waktu kontak 90 menit dengan konsentrasi antara 2000 ppm dapat membunuh hampir 100\% larva nyamuk.

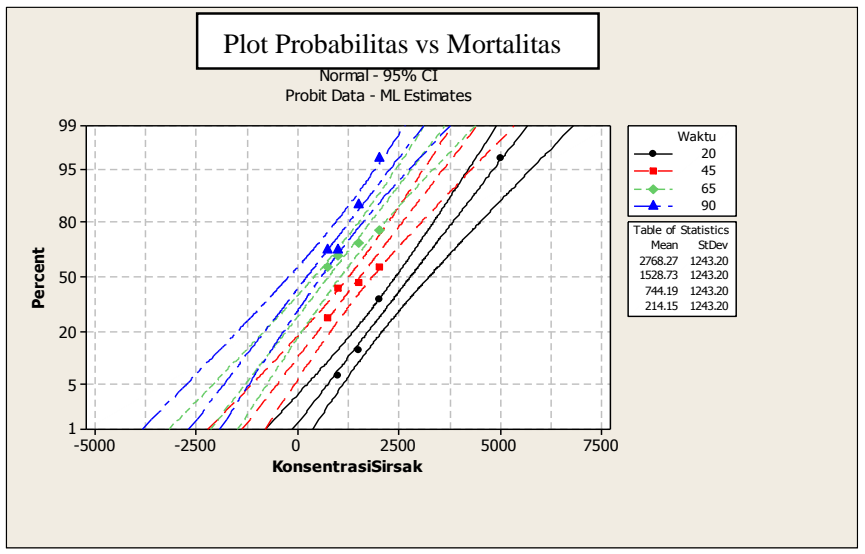

Gambar 1. Hubungan Konsentrasi Ekstrak Daun sirsak Dengan Waktu

Gambar 1. menunjukan bahwa konsentrasi larutan yang kecil dalam waktu yang lebih lama, maka tingkat kematian larva akan semakin meningkat dan sebaliknya jika konsentrasi yang tinggi dalam waktu yang singkat pun akan dapat membunuh larva dengan tingkat kematian yang tinggi. Untuk membunuh larva nyamuk jika dengan menggunakan waktu kontak 20 menit membutuhkan konsentrasi yang tinggi tetapi dengan jika dengan waktu kontak 90 menit hanya membutuhkan konsentrasi yang kecil oleh karena itu ektrak daun sirsak digolongkan cukup toksik dalam membunuh larva nyamuk Aedes aegypti.

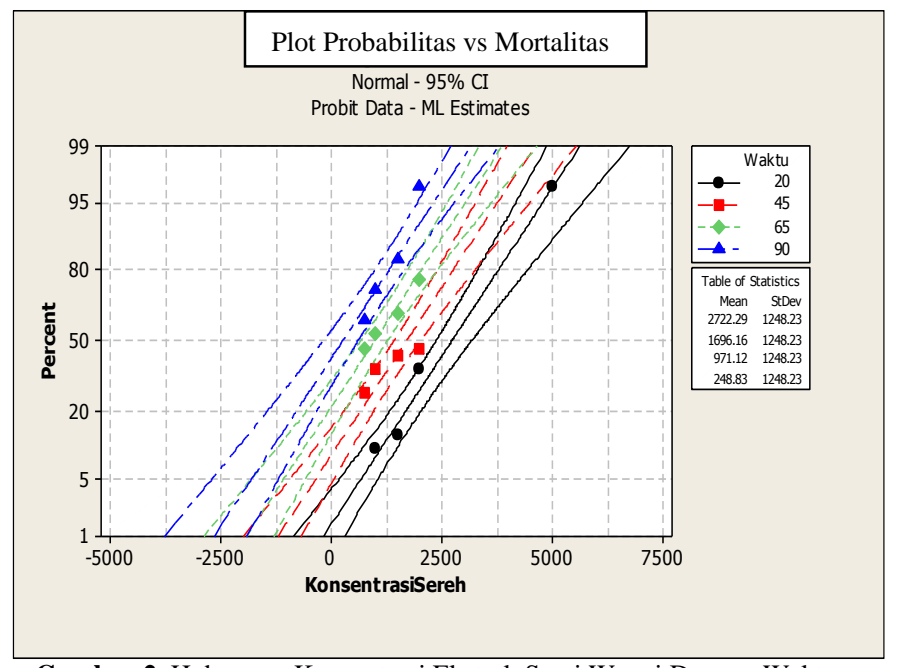

Gambar 2. Hubungan Konsentrasi Ekstrak Serai Wangi Dengan Waktu

Gambar 2 di atas menunjukan bahwa konsentrasi larutan yang kecil dalam waktu yang lebih lama, maka tingkat kematian larva akan semakin meningkat dan sebaliknya jika konsentrasi yang tinggi dalam waktu yang singkat 
pun akan dapat membunuh larva dengan tingkat kematian yang tinggi. Untuk membunuh larva nyamuk jika dengan menggunakan waktu kontak 20 menit membutuhkan konsentrasi yang tinggi tetapi jika dengan waktu kontak 90 menit hanya membutuhkan konsentrasi yang kecil oleh karena ekstrak serai wangi digolongkan cukup toksik dalam membunuh larva nyamuk Aedes aegypti.

Berdasarkan hasil analisis Minitab 16 dan $\mathrm{LC}_{50}$ tersebut menunjukan persentasi dan grafik kematian larva nyamuk Aedes aegypti dari ekstrak daun sirsak dan serai wangi, sehingga dapat diketahui ekstrak mana yang lebih efektif dan beracun yang digunakan sebagai biolarvasida.

\subsection{Pembahasan}

Pembiakan larva nyamuk Aedes aegypti dilakukan pada bak penampungan air yang sudah dibersihkan dan diisi dengan air bersih secukupnya. Bak ditutup dengan sehelai karung sehingga intensitas cahaya menjadi gelap selama 2 minggu. Setelah kurang lebih 1 minggu, bak penampungan air diperiksa untuk mengetahui keberadaan telur sudah ada sampai telur nyamuk ditetaskan menjadi larva. Setelah 2 minggu saat telur nyamuk telah menjadi larva, larva diambil dan dipindahkan kedalam toples untuk selanjutnya dibawa ke laboratorium dan di jadikan sebagai bahan penelitian.

Uji aktifitas ekstrak daun sirsak dan serai wangi yang efektif dalam membunuh larva nyamuk Aedes aegypti terjdi pada konsentrasi yang tinggi yaitu 5000ppm. Ekstrak dari daun sirsak dan serai wangi dijadikan biolarvasida karena mengandung senyawa-senyawa kimia berupa zat asetogenin seperti annonin atau annonasin, bulatasin, bulatasinon, skuamosin asimisin, dan annonastatisn pada ektrak daun sirsak dan senyawa-senyawa geraniol, sitral, nerol, metal heptenon, dan dipentena pada ekstrak serai wangi (Wahyuni \& Loren, 2015). Zat-zat tersebut memiliki efek toksis ketika di makan oleh serangga dan dapat menghambat pertumbuhan, mempengaruhi sistem saraf, perkembangan reproduksi serangga, menghambat pernapasan sehingga mampu menyebabkan kematian.

Perbandingan perlakuan antara ekstrak daun sirsak dan serai wangi yang lebih efektif dalam membunuh larva nyamuk adalah ekstrak daun sirsak terlihat pada perbandingan jumlah larva yang mati pada tabel 1 dan tabel 2 pada konsentrasi 1500ppm di menit ke 90. Ekstrak daun sirsak lebih banyak mengandung senyawa-senyawa kimia yang aktif dan beracun dibandingkan ekstrak serai wangi karena tumbuhan serai wangi lebih banyak mengandung citronela oil atau minyak atsiri sehingga ekstrak daun sirak lebih efektif dibandingkan ekstrak serai wangi (Rosdiani, 2015).

Penelitian-penelitian sebelumnya yang sudah dilakukan oleh beberapa peneliti seperti "Ekstrak Daun Sirsak Dalam Membunuh Jentik Nyamuk" dilakukan dengan mensurvei bak-bak penampungan air sebelum dilakukan intervensi, pembuatan ekstrak daun sirsak dilakukan dengan metode infusa $10 \%$. Ekstrak daun sirsak yg telah diperoleh, digunakan secukupnya dan jentik nyamuk mati dalam waktu selama 6 jam (Harfriani, 2012). Penelitian lainnya tentang "Pengaruh Daya Tolak Perasan Serai Wangi Terhadap Gigitan Nyamuk Aedes aegypti" sebelum dilakukan penelitian diukur suhu dan kelembaban, konsentras yang digunakan berkisar $1 \%-4 \%$, setelah diperoleh air perasan serai wangi kemudian dilakukan pengenceran konsentrasi dengan menggunakan statistik, setelah itu perlakuan dilakukan selama 5 menit dan istirahat selama 25 menit (Manurung $d k k ., 2011$ ). Adapun penelitian lain tentang "Pengaruh Ekstrak Daun Kenikir (Tagetes erecta L) Sebagai Repellent Terhadap Nyamuk Aedes Spp" konsentrari yang digunakan $1 \%-5 \%$. Esktrak daun kenikir diperoleh dengan metode ektrasi yang moderen dengan alat-alat seperti penanggas air, rotary evaporator, dan perkolator. Ekstrak yang didapat kemudian dibuat menjadi lotion untuk dilakukan percobaan dan waktu yang digunakan 5 menit dengan jeda waktu 30 menit (Hutagalung $d k k$., 2013).

Pada hasil penelitian ini menunjukkan bahwa untuk mematikan larva nyamuk Aedes aegypti, menggunakan konsentrasi 5000ppm dalam waktu 90 menit. Hal ini disebabkan karena metode esktrasi yang digunakan untuk mendapatkan ekstrak daun sirsak dan serai wangi masih sangat sederhana menggunakan alkohol $70 \%$.

Menurut (Hutagalung $d k k ., 2013$ ) "Pengaruh Ekstrak Daun Kenikir (Tagetes erecta L.) sebagai Reppelent Terhadap Nyamuk Aedes spp. ”. Hasil ekstrak daun kenikir yang di rendam dengan etanol selama 24 jam menghasilkan ekstrak yang lebih pekat sehingga sangat efektif dalam membunuh larva nyamuk karena etanol sejenis cairan yang mudah menguap yang merupakan obat psikoaktif neurotoksik yaitu zat beracun yang apabila masuk kedalam tubuh langsung mempengaruhi dan menyerang sistem saraf. Etanol juga sebagai pelarut yang penting sebagai stok umpan untuk sintesis senyawa kimia lainnya.

\section{Simpulan}

Berdasarkan hasil penelitian yang telah dilakukan dapat disimpulkan bahwa ekstrak daun sirsak dan serai wangi mampu membunuh larva nyamuk Aedes aegypti dan dapat dijadikan biolarvasida. Ekstrak yang lebih efektif dalam membunuh larva nyamuk adalah ekstrak daun sirsak dibandingan ekstrak serai wangi terlihat pada jumlah persentase kematian larva. Waktu kontak yang efektif dalam membunuh larva adalah 90 menit dengan konsentrasi yaitu 2000ppm dapat membunuh hampir $100 \%$ larva.

\section{Saran}

Mengingat kekurangan dan keterbatasan dalam penelitian ini maka peneliti menyarankan:
1) Pada penelitian-penelitian selanjutnya sebelum melakukan penelitian sebaiknya memperhatikan suhu, kelembapan ruangan dan memperhatikan kondisi lingkungan sekitar agar penelitian dapat berlangsung dengan baik.

2) Metode dan cara pembuatan ekstrak lebih baik dilakukan dengan cara yang moderen dan dengan alat-alat yang moderen dilaboratorium-laboratorium yang lengkap untuk mendapatkan ekstrak dari tumbuhan yang lebih efektif.

3) Perbedaan jumlah konsentrasi yang digunakan mungkin lebih tinggi dari 5000ppm dengan waktu kontak yang mungkin lebih dari 90 menit atau beberapa hari. Setelah ekstrak dengan konsentrasi tersebut didapat kemudian bisa dilanjutkan dengan pembuatan lotion untuk hasil penemuan baru.

\section{Pustaka}

Harfriani, H. 2012. Efektivitas Larvasida Ekstrak Daun Sirsak dalam Membunuh Jentik Nyamuk. Jurnal Kesehatan Masyarakat, 7(2): 164-169.

Hutagalung, D., Marsaulina, I. \& Naria, E. 2013. Pengaruh Ekstrak Daun Kenikir (Tagetes Erecta L.) sebagai Repellent tehadap Nyamuk Aedes sp. Lingkungan dan Keselamatan Kerja, 2(2).

Jenova, R. 2009. Uji Toksisitas Akut yang Diukur dengan Penentuan LD50 Ekstrak Herba Putri Malu (Mimosa pudica L.) terhadap Mencit BALB/C.

Kolo, S.M.D. \& Oetpah, F. 2017. Aktivitas Biolarvasida Minyak Sereh Wangi (Cymbopogon citratus (DC) Stapf.) terhadap Larva Nyamuk Anopheles sp. SAINTEKBU, 9(2): 76-83.

Manurung, R., Chahaya, I. \& Dharma, S. 2011. Pengaruh Daya Tolak Perasan Serai Wangi (Cymbopogon nardus) terhadap Gigitan Nyamuk Aedes aegypti. Lingkungan dan Keselamatan Kerja, 2(1).

Rosdiani, A.M. 2015. Efek Ekstrak Daun Pepaya (Carica Papaya L) Sebagai Larvasida Terhadap Larva Nyamuk Culex Sp. Karya Tulis Akhir. [other] University of Muhammadiyah Malang.

Sitio, A. 2008. Hubungan Perilaku Tentang Pemberantasan Sarang Nyamuk dan Kebiasaan Keluarga dengan Kejadian Demam Berdarah Dengue di Kecamatan Medan Perjuangan Kota Medan Tahun 2008.

Sumi Arcani, N.L.K., Sudarmaja, I.M. \& Swastika, I.K. 2017. Efektivitas Ekstrak Etanol Serai Wangi (Cymbopogon nardus L) sebagai Larvasida Aedes aegypti. E-Jurnal Medika Udayana; Vol 6 No 1 (2017): E-jurnal medika udayana.

Wahyuni, D. \& Loren, I. 2015. Perbedaaan Toksisitas Ekstrak Daun Sirih (Piper betle L.) dengan Ekstrak Biji Srikaya (Annona squamosa L.) terhadap Larva Nyamuk Aedes aegypti L.

Wardani, S. 2009. Uji Aktivitas Minyak Atsiri Daun dan Batang Serai (Andropogon nardus L) sebagai Obat Nyamuk Elektrik terhadap Nyamuk Aedes aegypti. 